ERC Working Papers in Economics 17/17

December / 2017

\title{
Unemployment Invariance Hypothesis, Added and Discouraged Worker Effects in Canada?
}

\author{
Aysit Tansel \\ Department of Economics, Middle East Technical University, 06800, Ankara, Turkey. \\ Institute for Study of Labor (IZA), Bonn, Germany \\ Economic Research Form (ERF), Cairo, Egypt \\ e-mail: atansel@metu.edu.tr, Phone: +(90) 3122102073
}

\section{Zeynel Abidin Ozdemir}

Department of Economics, Gazi University, Besevler, 06500, Ankara, Turkey

Economic Research Form (ERF), Cairo, Egypt

e-mail: zabidin@ gazi.edu.tr, Phone: +(90) 3122121115 


\title{
Unemployment Invariance Hypothesis, Added and Discouraged Worker Effects in Canada?
}

\author{
Aysit Tansel \\ Department of Economics, Middle East Technical University, 06800, Ankara, Turkey. \\ Institute for Study of Labor (IZA), Bonn, Germany \\ Economic Research Form (ERF), Cairo, Egypt \\ e-mail: atansel@metu.edu.tr, Phone: +(90) 3122102073 \\ Zeynel Abidin Ozdemir \\ Department of Economics, Gazi University, Besevler, 06500, Ankara, Turkey \\ Economic Research Form (ERF), Cairo, Egypt \\ e-mail: zabidin@gazi.edu.tr, Phone: +(90) 3122121115
}

December 23, 2017

\begin{abstract}
This article explores the long-run relationship between unemployment rate and labor force participation rate for men and women in Canada. The co-integration analysis vindicates the existence of a long-run relationship between these two variables. This finding leads us to doubt the pertinence of the unemployment invariance hypothesis for Canada. This is consistent with the empirical studies for Japan, Sweden and the United States, but contradicts the empirical studies for Australia, Romania and Turkey. Further, we find discouraged worker effect for women and added worker effect for men and we elaborate on the possible explanations for this seemingly contradictory finding.
\end{abstract}

KEYWORDS: Unemployment Invariance; Unemployment; Labor Force Participation; Discouraged Worker Effect; Added Worker Effect; Co-integration; Canada JEL CLASSIFICATION: E24; J21; J64; 


\section{Introduction}

This article explores the long-run relationship between unemployment rate and labor force participation rate in Canada by gender. The nature of this relationship has wide implications for the labor market policy, macroeconomic policy as well as macroeconomic theory and modeling in applications. The informational value of the unemployment rate as an indicator of labor market conditions may not be reliable if there are changes in the labor force participation rate over the business cycle. Further, unemployment invariance hypothesis suggests that the labor market adjustments ensure that the long-run unemployment rate is independent of the labor force, capital stock and total factor productivity. The effect of the changes in these factors can be offset by the labor market adjustments via changes in labor demand, labor supply and wage setting. For instance, an increase in productivity due to technological progress shifts the labor demand curve to the right. According to the unemployment invariance hypothesis the wage setting curve shifts inward by the same amount leaving long-run unemployment unchanged with higher wages. Similar adjustments take place when capital stock increases. However, when there is an increase in the size of the labor force, labor supply shifts to the right. According to the unemployment invariance hypothesis the wage setting curve shifts to the right by the same amount leaving long-run unemployment unchanged with lower wages.

The validity of unemployment invariance hypothesis is a debatable topic among the macroeconomists. For the United Kingdom, Layard et al. (1991) support it while Karanassou and Snower (2004) reject it. Fitoussi et al. (2000) show that long-run unemployment rate is independent of the labor force participation, capital stock and productivity "but only in trendless combinations" in several OECD countries. Österholm (2010) for Sweden, Emerson (2011) for the United States, Kakinaka and Miyamoto (2012) (for males only) and Liu (2014) (from a regional perspective) for Japan do not find support for unemployment invariance hypothesis. Conversely, Otoiu and Titan (2015) for Romania, Tansel et al. (2016) for Turkey and Van (2016) for Australia find support for the unemployment invariance hypothesis. We ask the following questions. Does unemployment invariance hypothesis hold for Canada? Is this result similar to that observed in other countries? Do changes in unemployment rates set-off addedworker or discouraged-worker effects? Our main results indicate the following. We do not find support for the unemployment invariance hypothesis in Canada. It is consistent across men and women. This implies that long-run unemployment rate is not independent of the labor force in Canda. We further find added-worker effect for men and discouraged-worker effect for women. 
We elaborate on possible explanations for this seemingly contradictory observation. High labor force participation of women and generous unemployment insurance arrangements are possible reasons for our failure to find added-worker effect for women.

\section{Methodology}

In order to examine the existence of a long-run relationship between unemployment and labor force participation rates we apply the vector error correction (VEC) model to these variables. It is a restricted vector auto-regression (VAR) model which can be written as follows.

$$
y_{t}=\alpha+\sum_{i=1}^{k} A_{i} y_{t-i}+\varepsilon_{t}
$$

where $y_{t}$ is an $n$-vector of variables to be examined. $\varepsilon_{t}$ is independent, identically distributed random disturbance term. Equation (1) can be rewritten as:

$$
\Delta y_{t}=\alpha+\pi y_{t-1}+\sum_{t=1}^{k-1} r_{i} \Delta y_{t-i}+\varepsilon_{t}
$$

where $\pi=\sum_{i=1}^{k} A_{i}-I$ and $r_{i}=-\sum_{j=i+1}^{k} A_{j} . \pi$ has a rank $r(0 \leq r<n)$ where $r$ is the number of cointegrating vectors. We have $\pi=\alpha \beta^{\prime}$ and $\beta^{\prime} y_{t}$ is stationary. $\beta$ is the $n \mathrm{x} r$ matrix of rank $r$ elements of which are the co-integrating parameters. $\alpha$ is the $r \mathrm{x} n$ matrix of rank $r$ the elements of which are adjustment parameters (error-correction terms).

\section{Data}

We use monthly data on the unemployment rate (UN) and the labor force participation rate (LFPR) for the period January 1976 through December 2015. Given that there are differences in the unemployment rates and participation rates of men and women we perform separate analysis for them. The time series plot of the data are presented in Figure 1. We observe enormous increases in the female LFPR over the past half a century while male LFPR exhibits a decline over the same period. The unemployment rates exhibit cyclical variations. In this respect, we observe a similar pattern for the female and male unemployment rates. 
Figure 1. Labor force participation and unemployment rates, 1976:M1-2015:M12.
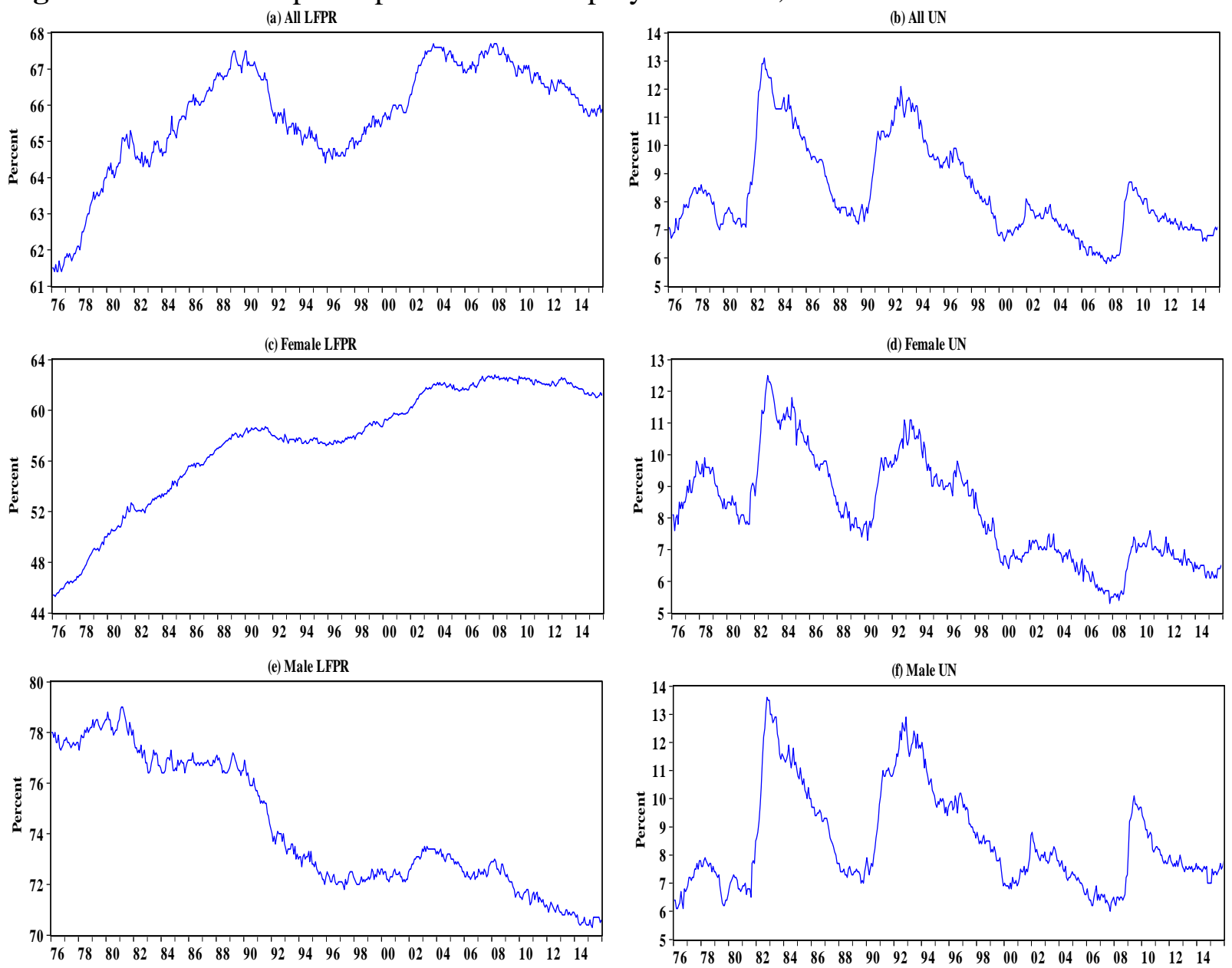

\section{Empirical Analysis}

We first investigate the time series properties of the unemployment rate and the participation rate series. We use Augmented Dickey-Fuller (ADF) unit root test with Generalized Least Square (GLS) detrending due to Elliot, Rothenberg and Stock (1996) as well as the KPSS test of Kwiatkowski, Phillips, Schmidt and Shin (1992). ADF-GLS tests indicate that the null hypothesis of non-stationarity cannot be rejected at 5 percent level of significance for all the series. The KPSS test results suggest that the null hypothesis of stationarity is rejected for all of the series at 5 percent level. These results indicate that all of the series are non-stationary i.e. have unit roots. 
Table 1. Univariate unit-root tests, Canada, 1976:M1-2015:M12.

\begin{tabular}{lcccccc}
\hline & \multicolumn{2}{c}{ All } & \multicolumn{2}{c}{ Men } & \multicolumn{2}{c}{ Women } \\
\cline { 2 - 7 } & LFPR & UN & LFPR & UN & LFPR & UN \\
\hline ADF-GLS & $0.41(1)$ & $-1.73(3)$ & $1.32(1)$ & $-1.59(3)$ & $1.65(5)$ & $-1.16(3)$ \\
KPSS & $1.37 *$ & $0.89 *$ & $2.48 *$ & $0.68 *$ & $2.38 *$ & $1.74 *$ \\
\hline
\end{tabular}

Notes: * indicates significance at the 5 percent level. The lag lengths (given in parentheses) are established using the Schwarz Information Criteria. ADF-GLS and KPSS tests both allow for a constant and both are one-sided tests of the relevant null hypothesis.

Next step is to test if there is a long-run relationship between UN and LFPR within a cointegration framework. Johansen's methodology $(1988 ; 1991)$ provide two complementary cointegration test statistics. They are the trace and the maximum-eigenvalue tests which are reported in Table 2.

Table 2. Multivariate Co-integration tests, Canada, 1976:M1-2015:M12.

\begin{tabular}{ccccccc}
\hline & \multicolumn{2}{c}{ All } & \multicolumn{2}{c}{ Males } & \multicolumn{2}{c}{ Females } \\
\hline Hypothesis & Trace & Maximum- & Trace & Maximum- & Trace & Maximum- \\
& statistics & eigenvalue & statistics & eigenvalue & Statistics & eigenvalue \\
\hline$r=0$ & $20.431^{*}$ & $15.541^{*}$ & $26.393^{*}$ & $26.205^{*}$ & $38.139^{*}$ & $33.679^{*}$ \\
$r \leq 1$ & 4.889 & 4.889 & 0.187 & 0.187 & 4.460 & 4.460 \\
\hline
\end{tabular}

Notes: Lag lengths in the VAR (in levels) are selected using the Akaike's Information Criteria (AIC).

*indicates significance at 5 percent level or better.

Both the trace and the maximum-eigenvalue tests indicate that the null hypothesis of noco-integration is rejected at 5 percent level or better and there is one and only one co-integrating vector in all cases considered. These results are robust since the two co-integration tests are in agreement as it is suggested by Hjalmarsson and Österholm (2010). Thus, there is a long-run relationship between the unemployment and labor force participation rates. Hjalmarsson and Österholm further warn that the trace and the maximum eigenvalue tests have size distortions when the series have near unit roots. They suggest further testing of the restrictions, $\beta=\left(\begin{array}{ll}1 & 0\end{array}\right)^{\prime}$ and $\beta=\left(\begin{array}{ll}0 & 1\end{array}\right)^{\prime}$. If they are both rejected then the co-integration holds. If both of them or either of them cannot be rejected then co-integration does not hold which may be due to a single stationary variable. To allow for the possibility of near unit roots we test the above restrictions with likelihood ratio tests. Table 4 indicates that both of the restrictions are strongly rejected implying that co-integration holds in all cases considered. The co-integrating vectors shown in 
Table 3 suggest the added-worker effect for men and discouraged-worker effect for women. Possible interpretations of this finding are elaborated on in Section 4.1.

Table 3. Estimated co-integrating vector, 1976:M1-2015:M12.

\begin{tabular}{lccc}
\hline & All & Male & Female \\
\hline LFPR & 1.000 & 1.000 & 1.000 \\
& & & \\
UN & 0.616 & -3.903 & 1.074 \\
& $(0.230)$ & $(0.788)$ & $(0.363)$ \\
\hline
\end{tabular}

Note: Standard errors are reported in parentheses.

*indicates significance at 5 percent level or better.

Finally we consider the short-run dynamics in the relationship between unemployment rate and the labor force participation rate. We test the following restrictions on the errorcorrection terms $\alpha=\left(\begin{array}{ll}\alpha_{1} & 0\end{array}\right)^{\prime}$ and $\alpha=\left(\begin{array}{ll}0 & \alpha_{2}\end{array}\right)^{\prime}$ with the likelihood ratio tests. The first restriction suggests that the labor force participation rate does error correct but the unemployment rate does not while the second restriction implies the opposite. As shown in Table 4 both restrictions are strongly rejected in all cases confirming that both the participation and the unemployment rates are weakly exogenous.

Table 4. Tests of restrictions in co-integrated VAR, Canada, 1976:M1-2015:M12.

\begin{tabular}{|c|c|c|c|}
\hline Restriction & All & Male & Female \\
\hline$\beta=\left(\begin{array}{ll}1 & 0\end{array}\right)^{\prime}$ & $\begin{array}{c}4.711 \\
(0.029)\end{array}$ & $\begin{array}{c}24.259 \\
(0.000001)\end{array}$ & $\begin{array}{c}4.782 \\
(0.028)\end{array}$ \\
\hline$\beta=\left(\begin{array}{ll}0 & 1\end{array}\right)^{\prime}$ & $\begin{array}{l}10.506 \\
(0.001)\end{array}$ & $\begin{array}{c}3.843 \\
(0.049)\end{array}$ & $\begin{array}{l}27.486 \\
(0.000)\end{array}$ \\
\hline$\alpha=\left(\alpha_{1} 0\right)^{\prime}$ & $\begin{array}{c}7.587 \\
(0.005)\end{array}$ & $\begin{array}{c}25.178 \\
(0.000001)\end{array}$ & $\begin{array}{c}12.943 \\
(0.0003)\end{array}$ \\
\hline$\alpha=\left(\begin{array}{ll}0 & \alpha_{2}\end{array}\right)^{\prime}$ & $\begin{array}{c}9.883 \\
(0.001)\end{array}$ & $\begin{array}{c}7.458 \\
(0.006)\end{array}$ & $\begin{array}{l}27.339 \\
(0.000)\end{array}$ \\
\hline
\end{tabular}

Notes: The $p$-values of the likelihood ratio tests for the restrictions are reported in the parenthesis.

\subsection{A Digression on Added and Discouraged Worker Effects}

In order to compensate for the income loss due to a spouse's job loss inactive spouse could become a labor market participant or increase the hours worked. It could be considered as a spousal labor supply as an insurance against unemployment. This is referred to as added-worker 
effect. Usually, it is empirically investigated as the responsiveness of the wife's labor supply to her husband's job loss. On the other hand, the discouraged-worker effect is defined as the voluntary withdrawal of the individuals from the labor market when unemployment rates are high and they lose their hopes of finding a job. Added-and discouraged worker effects both occur during a recession with opposite effects on the labor force participation. The addedworker effect implies an increase in the labor force participation and the discouraged-worker effect implies a decrease in the labor force participation. The two effects may co-exit as suggested by Mincer (1966) and the stronger effect dominates the other. The theoretical underpinnings of the added-worker effect are espoused by Ashenfelter (1980), Heckman and MaCurdy (1980) and Lundberg (1985). The theoretical effect is well established. However, in the empirical literature there is no consensus on the magnitude and the existence of addedworker effect.

The existence and the magnitude of the added-worker effect depend on labor market institutions, the labor market conditions, welfare institutions, employment uncertainty, liquidity constraints and culture. Added-worker effect may be more existing during recessions (Bryan and Longhi, 2017; Mattingly and Smith, 2010) and may be less existing during economic booms (Spletzer, 1997; Sullivan, 2008). Lundberg (1985), Maloney (1987; 1991) and Spletzer (1987) study the case of the US with the finding of small or non-existing added-worker effect. Benati (2001) finds support for the existence of a significant discouraged-worker effect in the US data. Cullen and Gruber (2000) and Ortigueira and Siassi (2013) suggest that added-worker effect could be crowded out by unemployment benefits. In such cases, public welfare benefits offer an alternative to spouse's entering the labor force. McGinnity (2002) find added-worker effect in West Germany but not in the UK due to the means-tested unemployment benefit system there which may discourage women from entering the labor force or they may leave the labor force. Added-worker effect is mostly found in countries where female labor for participation is relatively low (Prieto-Rodriguez and Rodriguez-Gutierrez, 2000) and the welfare state is weak (Bentolila and Ichino, 2008). Bredtman et al. (2017) find that added-worker effect is strongest in the Mediterranean countries and weakest in the Aglo-Saxon countries. In fact, they find negative added-worker effect in the Anglo-Saxson countries which has means-tested unemployment benefit system. Kell and Wright (1990) also find a negative added-worker effect in the UK due to means-testing unemployment benefit system. Hardoy and Schøne (1014) finds no addedworker effect for the full sample of households in Norway which has a generous welfare state and high participation rate of women. 
There are several studies in Canada on added and discouraged worker effects. The literature on their empirical investigation goes back to the 1960's (Officer and Anderson, 1969). However, there is a revival of interest on this topic recently. Beland-O'Keefe (2004) provides an excellent survey of the literature of the empirical work in Canada. She finds discouraged-worker effect for the two time periods she examines for both men and women in Canada.

In this study we find a significantly negative coefficient estimate for women on the relationship between participation and unemployment rates. This could be due to the dominance of the discouraged-worker effect over the added-worker effect for women or it may also imply a negative added-worker effect due to the generous welfare state as explained above. We cannot distinguish between them in the context of a time series aggregate data. In Canada labor force participation rate is high as it is in most Western countries where married women already participate in the labor market in large numbers and many families are two-earner families. As Figure 1 indicates the labor force participation rate in Canada increased substantially since the 1970's. In 2015, the last year of our sample, it was 61.2 percent. This could be a reason as to why we do not find evidence for the existence of added-worker effect for women. Further, in general, all employees are eligible for unemployment insurance in which benefits are earnings related and the welfare is needs-tested in Canada (OECD, 2015). These imply that generous welfare arrangements in Canada could be crowding out the added-worker effect.

In this study we also find a significantly positive coefficient estimate for men on the relationship between participation and unemployment rates. This implies that the added-worker effect dominates the discouraged worker effect for men. This may be due to the fact that men are more likely to remain in the labor force when they become unemployed. More clearly, they may not exit the labor force due to being discouraged when they fail to find a job since they are in general the primary workers in the families.

\section{Conclusion}

This paper provides evidence that there is a long-run equilibrium relationship between labor force participation rate and unemployment rate in Canada. This result holds also when gender specific data are used conforming that unemployment invariance hypothesis is not supported in Canada. This implies that long-run unemployment is not independent of the labor force 
participation.This result is similar to the Karanassou and Snower (2004) for the United Kingdom, Österholm (2010) for Sweden, Emerson (2011) for the United States and Kakinaka and Miyamoto (2012) for Japan (male sample). However, our result contradicts Layard et al. (1991) in the United Kingdom, Tansel et al. (2016) in Turkey, Otoiu and Titan (2015) in Romania and Van (2016) Australia. The lack of support for the unemployment invariance hypotheses implies that changes in the participation rate which may be due to aging population will affect the unemployment rate in the long-run. Similarly, policies of early retirement or constraints on working time which reduce effective working age population may influence the long-run unemployment rate. Further, policies which improve technology, encourage investment, capital accumulation or research and development will also affect the unemployment rate in the long-run. It is important for the policy makers to plan for the long-run implications of these developments in the labor force participation of men and women.

We further find evidence for added-worker effect for men and discouraged-worker effect for women in Canada. This is contrary to what is found in the United States where there is discouraged worker effect especially for men. In the case of Canada the added-worker effect for women may be less important than the discouraged worker effect because of the strong labor force participation of women and the observation that many families are now two-earner families. Further, the generous welfare regime in Canada may be crowding out the addedworker effect and this could be a reason for the observation of negative added-worker effect. Although the finding of added-worker effect for men is more difficult to explain we conjecture that men as the primary workers may not withdraw from the labor force during an economic downturn. It is important from the policy making perspective to understand the response of the labor force participation to the changes in the demand for labor over the business cycle since it significantly affects the economy.

The findings in this paper will contribute to our understanding of the functioning of the labor market in Canada. The diversity of the evidence with respect to different countries should be investigated. It may be due to the differences in labor market institutions which may influence the adjustment mechanisms in different labor markets. 


\section{References}

Ashenfelter, O. (1980), "Unemployment as Disequilibrium in a Model of Aggregate Labor Supply", Econometrica, vol.48 (3), 547-564.

Béland-O'keefe, L. (2004) An Examination of the added-and the discouraged-worker effects in Canada at the end of the millennium. MA thesis. Deparment of Econmics, University of Ottawa.

Benati, L. (2001), "Some empirical evidence on the 'discouraged worker'effect", Economics Letters, vol.70(3), 387-395.

Bentolila, S. and Ichino, A. (2008), "Unemployment and consumption near and far away from the Mediterranean", Journal of Population Economics, vol.21 (2), 255-280.

Bredtmann, J., Otten, S., and Rulff, C. (2017), "Husband's Unemployment and Wife's Labor Supply-The Added Worker Effect across Europe", Industrial and Labor Relations Review, forthcoming.

Bryan, M. and Longhi, S. (2017), “Couples' Labour Supply Responses to Job Loss: Growth and Recession Compared", The Manchester School, forthcoming.

Cullen, J. B. and Gruber, J. (2000), "Does unemployment insurance crowd out spousal labor supply?", Journal of Labor Economics, vol.18 (3), 546-572.

Elliot, G., Rothenberg, T. J. and Stock, J. H. (1996), "Efficient tests for an autoregressive unit root",Econometrica, vol. 64, pp. 813-36.

Emerson, J. (2011), "Unemployment and labor force participation in the United States", Economics Letters, vol. 111, pp. 203-6.

Fitoussi, J. P., Jestaz, D., Phelps, E. S., Zoega, G., Blanchard, O., and Sims, C. A. (2000), "Roots of the recent recoveries: labor reforms or private sector forces?", Brookings Papers on Economic Activity, vol.1, 237-311.

Gustavsson, M. and Österholm, P. (2006), "The informational value of unemployment statistics: a note on the time series properties of participation rates", Economics Letters, vol. 92, pp.428-433.

Hardoy, I. and Schøne, P. (2014), "Displacement and household adaptation: insured by the spouse or the state?", Journal of Population Economics, vol.27 (3), 683-703.

Heckman, J. J. and MaCurdy, T. E. (1980), “A life cycle model of female labour supply", The Review of Economic Studies, vol.47 (1), 47-74.

Hjalmarsson, E., and P. Österholm. (2010), "Testing for Cointegration Using the Johansen Methodology When Variables are Near-Integrated: size distortions and partial remedies", Empirical Economics, vol.39, pp.51-76.

Johansen, S. (1988), "Statistical analysis of cointegration vectors", Journal of Economic Dynamics and Control, vol. 12, pp. 231-54.

Johansen, S. (1991), "Estimation and hypothesis testing of cointegration vectors in Gaussian vector autoregressive models", Econometrica, vol. 59, pp. 1551-80.

Kakinaka, M. and Miyamoto, H. (2012), "Unemployment and labour force participation in Japan”, Applied Economics Letters, vol. 19, pp. 1,039-43.

Karanassou, M. and Snower, D. J. (2004), "Unemployment invariance", German Economic Review, vol. 5, pp. 297-317.

Kell, M. and Wright, J. (1990), "Benefits and the Labour Supply of Women Married to Unemployed Men", The Economic Journal, vol.100 (400), 119-126.

Kwiatkowski, D., Phillips, P. C., Schmidt, P. and Shin, Y. (1992), "Testing the null hypothesis of stationarity against the alternative of a unit root: How sure are we that economic time series have a unit root?", Journal of Econometrics, vol. 54, pp. 159-78.

Layard, R., Nickell, S. and Jackman, R. (1991) Unemployment: Macroeconomic Performance and the Labour Market, Oxford University Press, Oxford.

Lundberg, S. (1985), “The added worker effect”, Journal of Labor Economics, vol.3 (1), 11-37. 
Maloney, T. (1987), "Employment constraints and the labor supply of married women: A reexamination of the added worker effect", The Journal of Human Resources, vol.22 (1), $51-61$.

Maloney, T. (1991), "Unobserved variables and the elusive added worker effect", Economica, vol.58 (230) 173-187.

Mattingly, M. J. and Smith, K. E. (2010), "Changes in Wives' Employment When Husbands Stop Working: A Recession-Prosperity Comparison”, Family Relations, vol.59 (4), 343357.

McGinnity, F. (2002), "The Labour-force Participation of the Wives of Unemployed Men: Comparing Britain and West Germany Using Longitudinal Data", European Sociological Review, 18 (4), 473-488.

Mincer, J. (1966) Labor-force participation and unemployment: a review of recent evidence. In: Gordon, R.A., Gordon, H.S. (Eds.), Prosperity and Unemployment. Wiley, New York.

OECD (2015) Economic Outlook. Paris: OECD.

Officer, L. and Anderson, P. (1969), "The Labour force Participation in Canada", Canadian Journal of Economics, vol.2, 278-287.

Ortigueira, S. and Siassi, N. (2013), "How important is intra-household risk sharing for savings and labor supply?", Journal of Monetary Economics, vol.60 (6), 650-666.

Oţoiu, A. and Ţiţan, E. (2016), "Does the unemployment invariance hypothesis hold for Romania?", Applied Economics Letters, vol.23(12), pp. 884-887.

Osterholm, P. (2010), "Unemployment and labour-force participation in Sweden", Economics Letters, vol. 106, pp. 205-8.

Prieto-Rodriguez, J. and Rodriguez-Gutierrez, C. (2000), "The added worker effect in the Spanish case", Applied Economics, vol.32 (15), 1917-1925.

Spletzer, J. R. (1997), "Reexamining the added worker effect", Economic Inquiry, 35 (2), 417427.

Sullivan, J. X. (2008), "Borrowing During Unemployment - Unsecured Debt as a Safety Net", The Journal of Human Resources, vol.43 (2), 383-412.

Tansel, A., Ozdemir, Z. A., and Aksoy, E. (2016), "Unemployment and labour force participation in Turkey", Applied Economics Letters, vol.23(3), pp.184-187.

Van, P. N. (2016), "Examining the unemployment invariance hypothesis: The case of Australia", The Australian Economic Review, vol. 49(1), pp. 54-8. 